\title{
Pekka Suutari
}

\section{SANTTU KARHU: LAULAJA- LAULUNTEKIJÄ RAJALLA}

Perestroikan myötä paikallistasolla olleet etniset jännitteet rävähtivät esiin Venäjällä. Suomen vastaisella rajalla sijaitsevassa Karjalan tasavallassa havahduttiin erityisesti siihen, että kylistäkin kieli oli katoamassa ja että kansallisen perinteen tulevaisuus oli vakavasti uhattuna. Neuvostoliiton poliittisen hegemonian murtuminen vauhditti kulttuurisia uudistusprosesseja ja synnytti neuvostomenneisyydelle kriittistä keskustelua. (Smith 2013: 280.) Samaan aikaan Suomessa kansallisen perinteen mukaisen kulttuurin ystäville aiemmin tuntemattomasta ja luoksepääsemättömästä rajamaasta tuli yhtäkkiä kansallisromanttinen kiinnostuksen kohde. Sieltä löytyi mielenkiintoista musiikkia, ääniä kadonneesta yhteydestä Suomen ja Karjalan kulttuuri- ja kieliperintöjen välillä. Musiikkia myös tuotettiin Suomeen (ja muihin maihin), ja samalla ylirajainen vaikutus tuntui myös Karjalan folkrockin kehityksessä.

Tässä artikkelissa käsittelen Karjalan tunnetuimman laulaja-lauluntekijän Santtu Karhun tuotantoa ja hänen suhdettaan karjalaisuuteen. Artikkelissa luodaan katsaus siihen kansalliseen ja karjalankieliseen viitekehykseen, jossa Santtu Karhu on toiminut 1980-luvun lopulta 2000-luvulle. Pääasiallisena lähteenä ovat Santtu Karhun äänitteet, demot ja äänilevyt, vuodesta 1988 vuoteen 2009. Artikkelissa pyrin vastaamaan kysymyksiin, miten karjalan kielen ja karjalaisten asema näyttäytyy Santtu Karhun tuotannossa ja miten hänen monimerkityksisiä tekstejään voidaan tulkita karjalaisten kansallisten kysymysten valossa hänen aktiivivuosinaan. Entä mikä oli rajatekijän ja naapurimaa Suomen vaikutus Venäjän Karjalan musiikkiin? Miten lauluntekijät ja muusikot itse näkivät karjalaisen

(c) SES \& Pekka Suutari, Etnomusikologian vuosikirja 2014, vol. 26, ss. 102-128 
kulttuurin elinmahdollisuudet? Santtu Karhun sanoituksia ja musiikkituotantoa tarkastelen pääasiassa kronologisessa järjestyksessä nostaen erilaisia keskeisiä teemoja esiin hänen tuotannostaan eri aikoina ja eri albumeilla.

Venäjän karjalaiselle kulttuurille Suomi-tekijä, raja-alueen historia ja ylirajaiset suhteet, ovat olennaisia. Suomalaiset ovat kautta aikain matkustaneet ja tutkineet Karjalaa - jopa enemmän kuin venäläiset tiedemiehet (Sihvo 2003: 70; Paskov 2012: 202). Erityisen hyvin Karjala-kiinnostus on näkynyt 1990-luvulla jälleen virinneessä kulttuuriturismissa ja ylirajaisessa taiteen ja kulttuurin vuorovaikutuksessa. Venäjän Karjalassa kansalliseen kulttuuriin herääminen tapahtui järjestöjen kokouksissa, kulttuuritoiminnassa ja juhlissa sekä ilmeni kulttuuri- ja kielipoliittisissa keskusteluissa karjalaisten asemasta (Lahikainen \& Mashin 1993; Birin 1996: 28-33). Santtu Karhun koko taiteellinen tuotanto näyttää ponnistavan juuri näistä karjalaisen kansan kohtaloon ja identiteettiin liittyvistä kysymyksistä, ja näiden ajatusten ja taiteellisten ihanteiden jakajina ovat olleet paitsi yleisö Venäjän Karjalassa myös ennen muuta Suomessa.

Santtu Karhu on suuri yksinäinen karjalankielisen folkrockin tekijä. Hänen musiikkinsa on saanut impulssia siitä kysynnästä, jota Suomessa tunnetaan kansallista karjalaista kulttuuria kohtaan, mutta myös siitä historiasta, jossa karjalainen kansa on elänyt rajalla (Sihvo 2003: 47; Klement'ev 1991). Tämän vuoksi tarkastelen tässä artikkelissa Santtu Karhun toimintaa muusikkona Venäjällä ja Suomessa, sekä hänen teksteissään välittyviä käsityksiä raja-alueella elävien karjalaisten elämästä. Tutkin myös, millainen vaikutus hänellä on ollut karjalaisen kulttuurin näkyvyyteen ja erityisesti karjalan kielen säilymiseen. Ainoana merkittävänä karjalankielisen rokkarina hän on tuonut oman kielensä aivan uudenlaiseen modernin lauletun lyriikan kontekstiin.

Voidaan sanoa, että Santtu Karhun tuotannolle keskeistä on paitsi konkreettinen valtioiden raja (Suomen ja Venäjän Karjalan välillä), myös symbolinen raja karjalaisen ja venäläisen kulttuurin välillä. Lisäksi varsinkin tuotannon alkuaikoina korostui hänen sukupolvensa kokema yhteiskunnallinen raja Neuvostoliiton ajan hallintovaltaan ja sen kulttuurisesti dominoivaan politiikkaan. Santtu Karhun sanoituksista voidaan nähdä karjalaisten taistelu olemassaolostaan venäläisyyden puristuksessa. Symbolinen rajanveto on tässä tilanteessa keino tuoda karjalaisuutta esiin erityisenä luontoon, kyläkulttuurin ja kieleen kiinnittyvänä kulttuuriperintönä ja etnisyytenä. Artikkelin tarkoituksena on myös tarkastella hänen tekstiensä 
keskeisten teemojen muutosta karjalan kielen pelastamisesta ja Suomi-tekijän käsittelystä yhä kasvavaan turhautumiseen, yksinäisyyteen ja absurdiuteen.

Santtu Karhu (oik. Aleksandr Medvedev, s. 1967) on kirjoittanut lauluja itsensä esitettäväksi 1980-luvun lopulta alkaen. Lyriikkansa hän on kirjoittanut omalla kotimurteellaan Vieljärven seudun karjalan kielellä (livvin murteella). Karhu syntyi ja kasvoi Belomorskissa venäjänkielisessä satamakaupungissa Karjalan tasavallassa, mutta äitinsä sukulaisten hoivissa, Vieljärven Jyrkilässä, hän omaksui karjalan kielen ja karjalaisen maailmankuvan. Samalla hän myös kasvoi siihen pelkoon, jota karjalan kielen ja kulttuurin nopea katoaminen aiheuttivat. Kylien kollektivoinnin ja väestön poliittisen agitoinnin seurauksensa koko Neuvostoliitto oli joutunut 1900-luvulla ankaran poliittisen hallinnan kohteeksi. Myös Santtu Karhun sukulaiset saivat tästä osansa. Karhun kertoman mukaan hän itse on kulakkien ${ }^{1}$ jälkeläinen: suku on karkotettu vuonna 1937 Melličan kylästä (Karjalan tasavallassa) kulakkeina. Ketään ei surmattu, mutta yhdeksän lehmää kotitalossa oli liikaa.

\begin{abstract}
Minä tahdon hyvittää, kostaa, ihan sillä tavalla. Minun sukulaiset ovat kuolleet, viety. Minä tahtoisin omilla sanoilla hyvittää koko tämän tilanteen. Kuinka minä voisin? Enhän minä lähde miliisiksi. Kuinka minä voisin? Lauluilla. Millä muulla? Mitä minä osaan? Enhän minä mitään osaa. Lauluilla vain. (Karhu, haastattelu 28.4.2012.)
\end{abstract}

Santtu Karhu alkoi 1980-luvun lopulla nuorena runoilijana kirjoittaa tekstejä karjalaisten kohtalosta Karjalan kansallisten kirjailijoiden innostamana. Hänen ensimmäisten kappaleidensa joukossa oli neljä livvinkarjalaisen Vladimir Brendojevin (1931-1990) teksteihin tehtyä kappaletta. Brendojev oli selvästi Santtu Karhua vanhemman ikäluokan runoilija, joka oli vasta 1980-luvulla alkanut kirjoittaa runoja karjalaksi (Mironova 2010: 163). Hän kannusti Karhua eteenpäin urallaan, vaikka ei ymmärtänytkään rockia: "se on kuin kipu hampaassa", kuten hän kirjoitti kirjeessä Karhulle (Suutari \& Munne 2013: 163). Karhun missiona oli kuitenkin uudistaa karjalankielisen musiikin sisältöä, tehdä nimenomaan folkrockia, jotta nuoret löytäisivät karjalan kielen ja karjalaisen identiteetin (Karhu, haastattelu 2007). Tässä mielessä hän jatkoi kansallisen intelligenssin tehtävää, mutta uusissa oloissa Neuvostoliiton rajalla.

I Porvarillisuudesta syytettyjen varakkaiden talonpoikien nimitys Neuvostoliitossa. 


\section{Rajatutkimus ja etnomusikologia}

Etnomusikologian ajattelutavan mukaan taiteeseen ja kulttuuriin ei voida soveltaa ulkopuolelta asetettuja normeja, vaan musiikin merkitys on kontekstisidonnaista. Etnomusikologian anti rajatutkimukselle perustuu tutkijan pyrkimykseen analysoida kulttuuria sen "sisäpuolelta", tekijöiden ja vaikuttajien näkökulmasta. (Nettl 1983: 131-132; Moisala 2013: 10; Berger 2008: 70.) Tämän vuoksi tarkastelen tässä artikkelissa Santtu Karhun tuotantoa ruohonjuuritasolla suhteessa hänen elinympäristöönsä Petroskoissa ja Karjalan kylissä sekä hänen ylirajaiseen yleisöönsä myös Suomessa.

Olennaisen tärkeä lähdeaineisto koostui Santtu Karhun (yhdessä Talvisovatyhtyeensä kanssa) tekemistä äänilevyistä ja demoista ${ }^{2}$ (ks. luetteloa artikkelin lopussa), mutta myös omista tutkijan kokemuksistani Santtu Karhun musiikin kuuntelijana - niin konserteissa, harjoituskämpällä kuin äänitteiltäkin. Työskentelin aiheen parissa yhdessä Timoi Munnen kanssa vuonna 2012, jolloin hän tutkimusapulaisen ominaisuudessa käänsi Karhun karjalankielisen tuotannon suomen kielelle (Suutari \& Munne 2013: 167; Karhu 2012). Laulutekstien kääntämisessä ratkaisevana apuna oli myös Santtu Karhu itse, sillä tekstit ovat vaikeasti selitettäviä ja monitulkintaisia. Karhun uraa olen seurannut jo pidemmän aikaa, tammikuusta 1992 lähtien, jolloin ensimmäisen kerran vierailin Petroskoissa ja tutustuin yhtyeeseen sen harjoituksissa. Karhu ei ole helppo haastateltava, sillä hän puhuu lyhyesti, satiirisesti ja usein vertauksin. Mutta pitempiaikainen tuttavuus on tehnyt hänen työskentelytapansa ja taiteellisen asenteensa sitäkin tutummaksi. Hänen uransa seuraaminen on myös mahdollistanut sen, että olen lukenut hänestä julkaistuja lehtihaastatteluja, nähnyt dokumenttifilmejä sekä tarkastellut hänen toimintaansa varsin tiiviisti yli 20 vuoden ajan.

Santtu Karhun tekemät kappaleet, sanoitukset ja sävellykset, pyritään tässä artikkelissa analysoimaan yhtenä kokonaisuutena. Eri kappaleita on yhteensä 73. Näkyväksi tehdään sekä Suomen vaikutus Karhun tekemään musiikkiin et-

2 Demoilla on yhteensä 61 kappaletta vuosilta 1988-1996. Useat niiden kappaleista on julkaistu myöhemmin erilaisina versioina Karhun albumeilla. Demoilla ja albumeilla olevien kappaleiden yhteenlaskettu määrä on 125 kappaletta ja toisinnot huomioon ottaen eri kappaleiden määrä yhteensä on 73. Yhtä (Aunuksen Anjaa) lukuun ottamatta kaikki kappaleet ovat Santtu Karhun sävellyksiä ja niiden sanoitukset ovat enimmäkseen livvinkarjalaksi kirjoitettuja. Varhaistuotantoon sisältyy myös muutamia suomenkielisiä teoksia, kuten Suomi takaisin. 
tä hänen rakentamansa symbolinen ja hegemoninen raja suhteessa Karjalassa yleistyvään venäläisyyteen ja naapurimaahan Suomeen (Ilyukha 2005). Teksteistä välittyy myös hänen suhteensa karjalaisille hyvin merkittävään suulliseen runouteen ja kansanperinteeseen. Muun muassa kalevalaiset aiheet ja sankarit esiintyvät myös hänen moderneissa lauluissaan. Keskityn artikkelissani ensisijaisesti Santtu Karhun teksteihin, vaikka pelkkää runoutta hänen lyriikkansa ei ole - hän pitää itseään etupäässä muusikkona ja hänen tekstinsä ovat kiinteä osa tätä kokonaisuutta, musiikkia (Karhun lähettämä viesti tekijälle 19.6.2011).

Toisinaan etnomusikologinen tutkimus pyrkii pääsemään tutkimuskohdettaan lähelle myös eettisistä syistä. Kulttuurisensitiivinen lähestymistapa tarjoaa paitsi monitahoista aineistoa tutkimuskohteeksi, myös laadullisen tuntuman siitä, että tutkittavana olevat kysymykset ja näkökulmat ovat tutkimuskohteille relevantteja ja merkityksellisiä (Kisliuk 2008: 184; Rice 1994). Ajatus siitä, että etnomusikologi paitsi tallentaa ja analysoi, myös osallistuu kansallisen identiteetin tulevaisuudesta käytävään keskusteluun kysymysten herättelijänä, ei ole uusi (Bruner 1986). Tutkijoiden suhtautuminen tutkimuskohteeseen kanssakeskustelijoina on metodisesti ongelmallinen ja erityisen monimutkaiseksi sen tekee Venäjän valtion tapa hallita, hillitä ja rajata kansallisuuskysymyksistä käytävää keskustelua. Haastatteluissa Santtu Karhu kritisoi mielellään Venäjää ja sen valtaapitäviä, mutta tekee sen vihjaillen ja epäsuorasti, kuin vältellen suoraan asiasta puhumista. Näiden kysymysten tarkastelu ja tulkinta on tapahtunut paitsi haastatteluissa, myös tutkimushankkeeni puitteissa yhteistyössä venäläisten tutkijoiden kanssa vuosina 2007-2014 pidetyissä säännöllisissä tutkimusseminaareissa. (Suutari 2010a: 6; Joustavat etnisyydet 2014.) Suurin osa aineistosta on hankittu syksyllä 2011, jolloin olin neljä kuukautta vierailevana professorina Kielen, kirjallisuuden ja historia instituutissa, Karjalan tiedekeskuksessa Petroskoissa.

\section{Kansallinen Karjala}

Kansallinen paikallinen kulttuuri oli Neuvostoliitossa erityissuojelussa, mutta sen esittämisen tavat olivat tarkasti säädellyt (Olson 2004: 54-55; Hirsch 1997: 264). Karjalan tasavallan tehtävänä oli karjalaisen ja vepsäläisen väestönosan 
kehittäminen, vaikkakin neuvostovallan aikana suomen kieli toimi tasavallan toisena virallisena kielenä (venäjän ohella) ja kansallisen taiteen lähtökohta (esim. kirjallisuudessa, teatterissa ja musiikissa) oli useammin suomenkielisessä kulttuurissa kuin karjalaisuudessa (Suutari 2010a: 10). Karjalan kielen kehitys miltei pysähtyi neuvostoajaksi ja käytännössä assimilaatiopaine kasvoi erityisesti 1950-luvulta alkaen, jolloin venäjää on pyritty käyttämään julkisten tilaisuuksien kielenä (Klement'ev 1991). Vaikka kansalliseen kulttuuriin kiinnitettiin paljon huomiota, karjalaisilla itsellään oli vähän vaikutusvaltaa karjalaista kulttuuria ja kansallisen kielen kehitystä koskevissa asioissa. Karjalan kieli ja karjalainen identiteetti näkyivät hyvin vähän arkielämässä (Laine 2002: 21).

Kansallisia tasavaltoja perustettiin eri puolille Neuvostoliittoa 1920-luvulla. Tuolloin vallitsevan ideologian mukaan alueen asukkaista oli oltava vähintään puolet niin sanottua kansallista väestöä - tässä tapauksessa karjalaisia, vepsäläisiä tai suomalaisia (Hyytiä 1999: 15). Karjalassa he joutuivat kuitenkin vähemmistöön jo 1920-luvulla. Suurimmaksi osaksi tämä selittyi muuttoliikkeellä, sillä teollistuva Karjala tarvitsi työvoimaa, jota saatiin etupäässä muilta Neuvostoliiton alueilta, mutta ajan mittaan myös assimiloituminen vähensi karjalaisten määrää ja osuutta muusta väestöstä. Venäjänkielistyneet karjalaiset alkoivat ilmoittaa itsensä venäläisiksi väestönlaskentatilastoissa. (Suutari 2010a: 9.) Paikallisia ongelmia ja esimerkiksi huolta pienten kielten kuolemasta ei voitu vapaasti nostaa keskusteluun (Kurki 2010: 106), eivätkä kansalliskielellä tehdyt kulttuuriesitykset seuranneet samalla tavoin kulttuurista uudistamista, kuin mitä tapahtui rajan takana Suomessa. Esimerkiksi rockin estetiikka ei soveltunut Neuvosto-Karjalan kansallisten perinteiden esittämiseen ennen perestroikaa. Kielen merkitys kansalliselle identiteetille oli suuri, mutta Neuvosto-Karjalassa suomen kielen valta-asema karjalaisen kansallisen vähemmistön asioista puhuttaessa osaltaan esti karjalan kirjakielen kehittymisen (Ylikangas 2004).

Karjalan kielellä oli kuitenkin laulettu ja kirjoitettu lauluja Neuvosto-Karjalassa aina siitä lähtien, kun kansantaide tehtiin kaiken taiteen ideologiseksi ja esteettiseksi esikuvaksi. Karjalan tasavallassa tunnettuja lauluntekijöitä olivat mm. Ivan Levkin (1901-1973), Anna Kolmyk ja Veikko Pällinen (1921-2001) (ks. Shvetsova 2007; Suutari 201ob: 220; Zhukova 1990). 1980-luvun nuoren sukupolven ääni kansallisen kulttuurin puolesta nousi kuitenkin esiin perinteisen estraditaiteen rinnalle samalla kun poliittisestikin orientoitunut toimijuus lisään- 


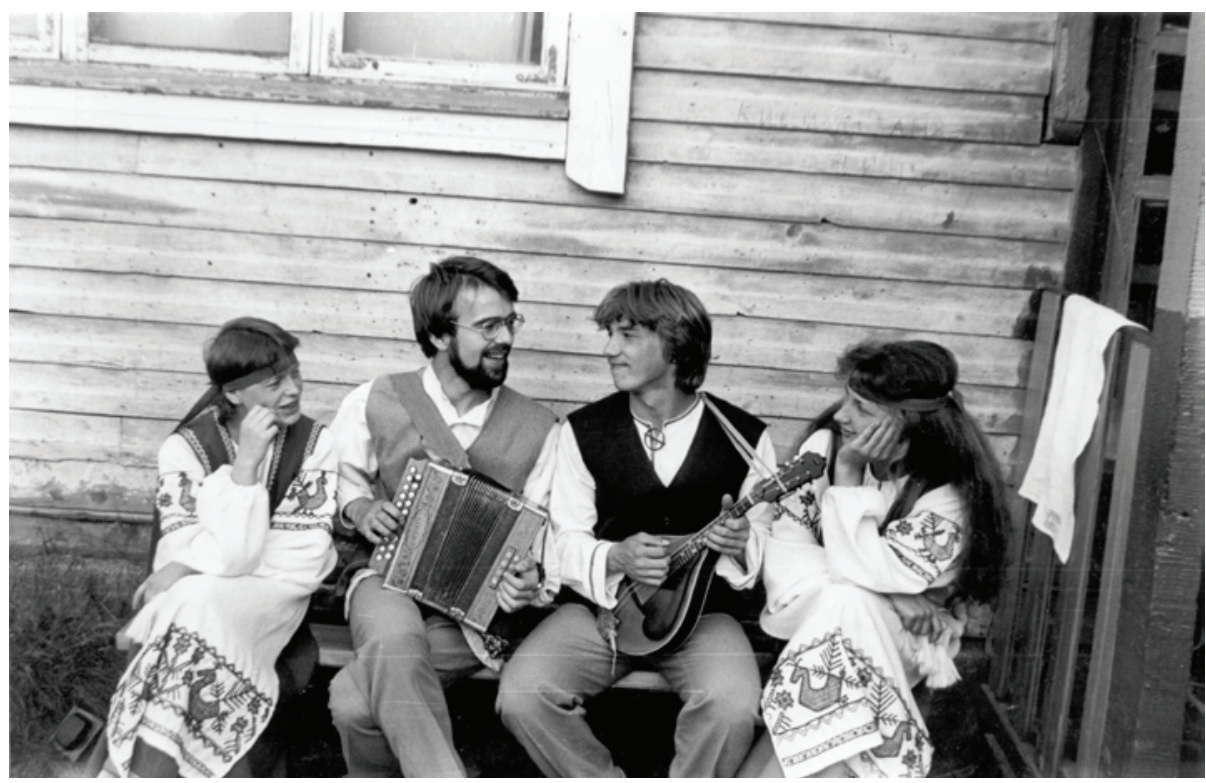

Kaksi laulajaa sekä soittajat Santtu Karhu ja Arto Rinne Petroskoin valtionyliopiston folkloreyhtyeessä 'Toive' vuonna 1985 (yllä), ja samat soittajat Talvisovat-yhtyeessä vuonna 1990 (alla). Rockin voiman tuoma muutos näkyy asenteessa, ilmeissä ja vaatetuksessa. Valokuvat Arto Rinteen kotiarkistosta.

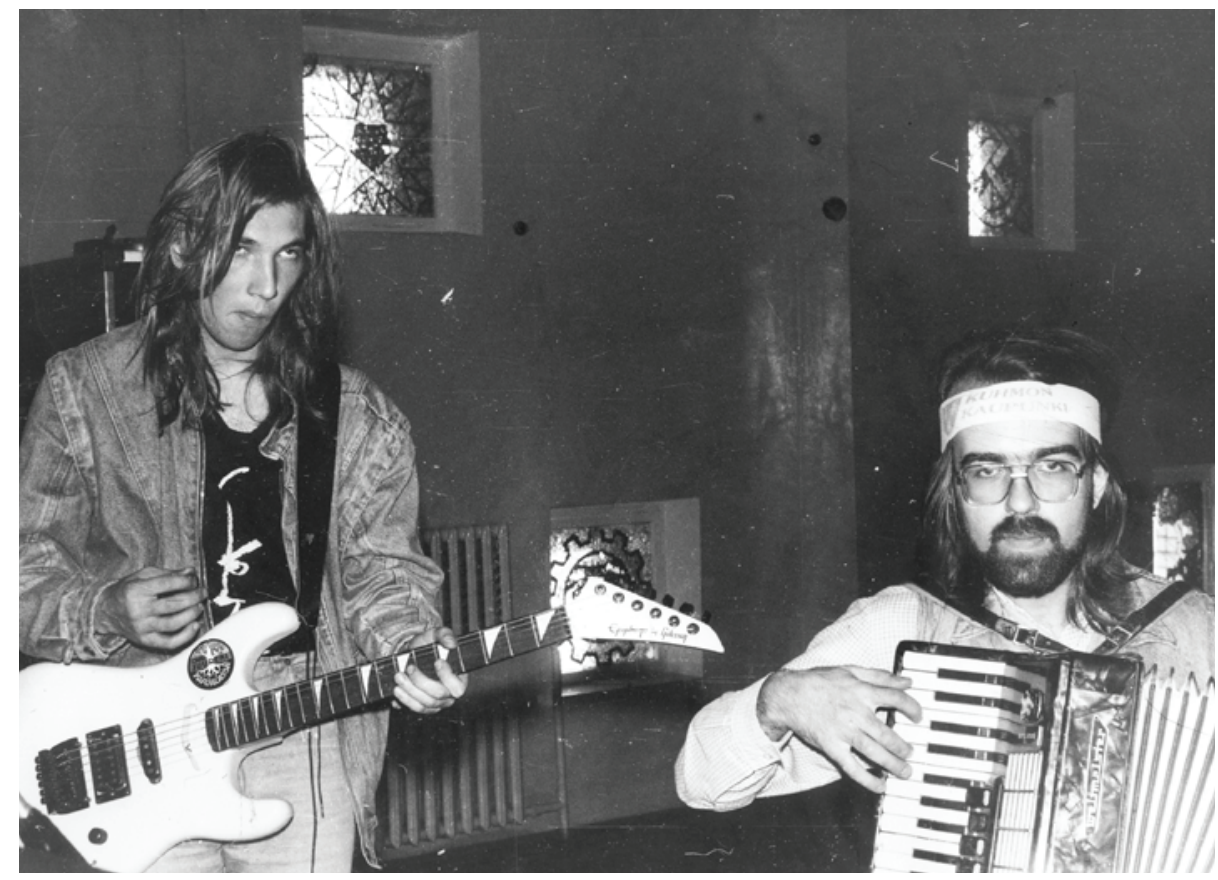


tyi (esim. Punalippu-lehdessä). Arkikäytössä kieli oli jo väistynyt venäjän tieltä, mutta erityisesti Petroskoin yliopiston nuoret opiskelijat kehittelivät omia suomen kielen kerhojaan, harrastivat kansanmusiikkia ja kirjoittamista. (KokkonenRoivas, haastattelu 2011).

Musiikki tavoittaa yleisöjä näiden kielitaidosta riippumatta ja kykenee puhuttelemaan yhtä lailla karjalaa tuntevia kuin vasta siihen tutustuviakin kuuntelijoita. (Musiikista taistelussa vähemmistökielen nostajana, ks. Jones-Bamman 2006.) Santtu Karhun ensimmäinen kiinnittyminen kansalliskieliseen musiikkiin tapahtui Petroskoin yliopiston folklore-yhtyeen välityksellä. Hän liittyi mandoliininsoittajaksi yhtyeeseen, vaikka ei vielä tuolloin ollut opiskelemassa itämerensuomalaisia kieliä Petroskoin yliopistossa. Yhtyeen estetiikan tietynasteisesta sovinnaisuudesta huolimatta innostus nuorten parissa oli suurta ja musiikin koettiin tuovan uudenlaisen, nuorten oman kansalliskielisen äänen, esiin. (Suutari 2012: 136; Rinne 2011.) Karhu halusi yhdessä ystävänsä Arto Rinteen kanssa kuitenkin ottaa askeleen pidemmälle kohti rajumpaa, vastakulttuurisempaa ja kriittisempää ilmaisua.

\section{Karhun tuotannon varhaiset laulut}

Santtu Karhun varhaistuotannon kantavana teemana on vastuu karjalan kielestä ja kansan tulevaisuudesta. Ajankohtaista 1980-luvun lopulla oli keskustella karjalan kielen tulevaisuudesta ja vaikuttaa karjalaisten kulttuurisen identifioitumisen prosessiin. Aihe herätti tuolloin paljon kiinnostusta ja innostusta karjalaisten parissa. Kysyin tästä Santtu Karhulta itseltään haastattelun aluksi.

Santtu Karhu: Sillonhan vielä just tää perestroikahan paljon vaikutti, et silloin ihmisillä oli vielä vähän semmosta: no, nyt kohtahan parempaan päin ollaan tulossa mukamas. Tavallaan herätys. Koettiin näin ainakin silloin. Sillon kun Karjalan rahvahan liitossa oli kokouksissa sali oli täynnä. Toisella tavalla kun nyt.

Kirjailijakaarti vielä elossa ja no siitä on parikytä vuotta jo.

Kirjoittaja: Se toimi innoittajana sulle?

Santtu Karhu: Niin no, tottakai. (Haastattelu 7.10.2011) 
Karjalan kielen tilanne oli hälyttävä: kieli oli kuolemassa ja karjalaisten määrä vähenemässä, kun kylistä ihmiset alkoivat lähteä maailmalle onneaan etsimään. Karhun mukaan olisi ollut tärkeää, että karjalaiset olisivat nousseet puolustamaan esivanhempiensa perintöä. Asetelmassa on mukana poliittista uhmaa, kuten virolainen tutkija Jaan Õispuu (2013: 117) on todennut: "nuorten vihaisten miesten - - taisteleva sävy on kautta aikojen ollut luonteenomaista poliittisten murroskausien nuorille runoilijoille."

Tijjän mejjänmoizii löydyy äjjäl
hyö tulen ker ečitäh keskivpäiväl
sobuu igästy, tottu todistu
no pagei loitokse tozi se
kudai eččimättäh jäi
sen toven sanat kerran vai
unis kuunella sain

\author{
Tiedän, meidänlaisia löytyy paljon \\ he valon kanssa etsivät päivällä \\ ikuista sopua, totisinta totta \\ no pakeni kauas se tosi \\ joka etsimättä jäi \\ sen toden sanat \\ kerran vain unissa kuunnella sain \\ (Mustas kois 1988)
}

Santtu Karhun ensimmäisen singlen a-puoli Mustas kois (suom. Savupirtissä 1988) kertoo olennaisen Karhun suhteesta kansalliseen perintöön. Laulaja-minä istuu savupirtissä synkän pimeyden verkon ympäröimänä. Oman päänsä sisällä hän kuulee karjalankielisen laulun, joka jäi todellisuudessa laulamatta. Kielen uskottiin olevan kuolemassa ja monet olivat jo menettäneet toivonsa. Mutta laulaja ei voi unohtaa myöskään niitä edellisen sukupolven tulisieluja, jotka istuivat kielensä tähden vankilassa. Laulutekstin kolmannen säkeistön mukaan lapset ovat kielen unohtaneet, mutta kertojan sydämessä elää yhä toivo ja usko niihin harvoihin karjalaisiin, jotka sanovat kielen kuolemalle: "peräänny". He etsivät "totuutta ja hyvyyttä" ja kantavat huolta kansan tulevasta elämästä.

Singlen b-puoli Lykyn peräh (Onnea etsimään 1989) kertoo saman asian kääntöpuolen. Laulajan sinä-muodossa puhuttelema henkilö lähtee etsimään leveämpää elämää. Laulaja kuitenkin muistuttaa, että sellainen asenne johtaa unohdukseen ja merkityksettömyyteen. Mielenkiintoista kyllä - Neuvostoaikaa kun elettiin - päähenkilö ei lähde vain oman onnensa takia, vaan hän noudattaa hänelle annettuja käskyjä. Sokea totteleminen johtaa vain vihan siemen kylvöön. Lähtijän omaatuntoa painaa, mutta hän on tottunut huijaamaan itseään. Siksi Karjala saa jäädä. 
Yhtä selväsanainen on Santtu Karhun teksti Väinämöinen (1989). Siinä hän miettii Karjalan historiaa, kieltä jota on säilynyt kirjoitettuna jo (Novgorodin) tuohikirjoituksissa (1200-luvulta).

Karjala muuttui Karelijakse

kus on mies, ken kirjutti tuoheh?

Mies jätti meille taakan kannettavakse,

kannammo yhtes sen ielleh

Eläkkäh Karjala sydämis meijän,

nuori polvi anna diedoloil kätty

Heijän piäl konzu ripui hamar tai terä,

vaiku löydynyh ei kirves varttu
Karjala muuttui [venäläisittäin] Karelijaksi

Missä on mies, joka kirjoitti tuoheen?

Mies jätti meille taakan kannettavaksi

Yhdessä kannamme sitä tulevaisuuteen

Eläköön Karjala meidän sydämissämme

nuori polvi, anna isoisille kättä

Heidän päällään milloin riippui hamara tai terä, mutta löytynyt ei kirvesvartta.

Näihin viimeisen säkeistön lauseisiin tiivistyy Karjalan monivuosisatainen historia, vastuu tämän perinnön säilyttämisestä sekä sankarillisuus, jolla uhasta huolimatta on karjalaisten heimoa on pidetty elossa. Lopullista kuoliniskua ei vielä ole annettu. Karjalaisen mytologian ja Kalevalan sankarit Väinämöinen ja Ilmarinen ovat laulun nimen mukaisesti karjalaisten esikuvia, joita seurata: "uskonet heih, kiänny meih" (jos uskot heihin, liity meihin).

\section{Rajummin, rajaavammin}

Karhun ensimmäiset kappaleet olivat sävyltään tunnelmallisia ja pohdiskelevia. Hänen itsensä mukaan suurimpana innoittajana oli ajan henki: karjalaisjärjestöt vetivät salit täyteen kokouksissaan ja kansallisten kulttuurien elvyttämisestä puhuttiin kaikkialla (haastattelu 2011). Perestroikan myötä oli tunne että mennään parempaan suuntaan. Kun hänelle tarjoutui mahdollisuus tehdä ensimmäiset singlelevynsä Suomessa, oli se täysin ennen kuulematonta sen ajan Neuvosto-Karjalassa (Suutari \& Munne 2013). Samalla Karhun merkitys paikallisena muusikkona kasvoi (Kaartinen 1989). Hänen yhtyeessään Talvisovat soittivatkin muun muassa Leo Sevets jouhikkoa, Arto Rinne haitaria ja Fedor Astashov sähkökitaraa. Karhu itse soitti myös sähkökitaraa. Kaikki neljä olivat Karjalan tasa- 
vallan niin sanottuun kansalliseen väestöön kuuluvia nuoria: kaksi karjalaista, suomalainen ja vepsäläinen.

Bändin kasvaessa ja menestyksen tuottaman itseluottamuksen lisääntyessä, Karhun ilmaisuskaala laajeni huomattavasti. Hänen kappaleensa olivat yhtä kantaa ottavia kuin aiemminkin, mutta entistä vihaisemmassa sävyssä kirjoitettuina. Tundematoi-kappale (1990) arvostelee voimakkaasti Karjalaan tulleita tunkeutujia, jotka ottavat paitsi alueen vallan haltuunsa myös kutsuvat sen kanta-asukkaita räkänokiksi. Syyttävä sormi osoittaa sirppiä ja vasaraa, Neuvostoliiton valtiollisia symboleja, jotka ovat vieneet Karjalan rikkaudet ja alistaneet sen heimon.

$\begin{array}{ll}\text { Hei tundematoi, ole tiä kui kois, } & \begin{array}{l}\text { Hei tuntematon, ole täällä kuin kotonasi, } \\ \text { oletgo karjalaine? }\end{array} \\ \text { oletko karjalainen? } \\ \text { Hei tundematoi, talvisovat söi koi, } & \text { Hei tuntematon, talvivaatteet söi koi, } \\ \text { oletgo karjalaine? } & \text { oletko karjalainen? } \\ \text { Cirpil leikattu on heinät meijän, } & \text { Sirpillä on leikattu heinät meidän, } \\ \text { Puittu vazaral on Karjalan heimo. } & \text { vasaralla on puitu Karjalan heimo. }\end{array}$

Kappaleen unisonossa vihaisesti laulettu kertosäe alleviivaa kappaleen sanomaa. Karjalaiset ovat kohdanneet vääryyttä, mutta anteeksi ei ole annettu eivätkä karjalaiset halua luovuttaa.

Omien aigoin legendat (Omien aikojen legendat 1990) on monitahoinen yhteiskuntakriittinen kuvaus muutoksen ajan Karjalasta. Tyhjiä lupauksia on annettu ja niillä pyritään sammuttamaan kansan henkinen palo. Vaikka perestroika on tuonut mahdollisuuksia avata yhteiskunnallista keskustelua, on silti vielä suitset tiukasti kiinni kansan hallitsemiseksi.

Minul sogiel sanottih - kiinitä vyö,

Rua - sit niken ei lyö,

yksikai nimid' et sua

Herru nosti käin, alevukkua lapset

Hos on vallendetty ohjakset,

ga löydyy suičet, päičet
Minulle sokealle sanottiin - kiinnitä vyö.

Tee työtä, eikä kukaan lyö,

mitään et kuitenkaan saa

Herra nosti kädet, vaietkaa lapset

Vaikka on löysätty ohjaksia

niin löytyy suitset ja päitset. 
Vajočču suo (Upottava suo 1991) kertoo, miltä kansasta tuntuu Neuvostoliiton romahtaessa. Kotimaan poliittinen kenttä on muurahaispesä, joka on vienyt tarinan kertojalta kaiken. Proletaarin elämä on kuin upottava suo, eikä tulevaisuus näytä valoisammalta. Romahdus ja henkinen turhautuminen tulivat odottamatta, kutsumatta: "ken katsoi sitä näkemättä?", kertosäkeistössä kysytään. Musiikilliselta kannalta kappale on suoraviivainen yksinkertainen rokkirenkutus. Sen hilpeä kepeys ikään kuin korostaa yhteiskunnan romahduksen raskautta, välinpitämättömyyttä.

\section{Suomi takaisin}

Talvisovat sai levyjensä myötä paljon kutsuja tulla esiintymään Suomeen folkfestivaaleille, karjalaisten kesätapahtumiin ja myöhemmin myös rockklubeihin ja -tapahtumiin. Yhtye kirjoitti keikka-autonsa kylkeen "Suomi takaisin", mikä oli kannanotto Suomessa vaiennettuun mutta vuosikymmeniä jatkuneeseen Karjala takaisin -keskusteluun (Santtu Karhu, suullinen tiedonanto). Suomen Neuvostoliitolle tekemien alueluovutuksen hyvittäminen oli perestroikan tuoman vapauden myötä nostettu julkiseen keskusteluun, mutta petroskoilaiset muusikot käänsivät ajatuksen toisin päin: Suomi tulisi liittää Karjalaan ja Petroskoista tehdä Suomen pääkaupunki.

Punkhenkisessä kappaleessa Suomi takaisin (1990) irvitään säilykkeillä syötetylle sukupolvelle Suomessa, joka tuskin selviäisi luonnonoloiltaan karussa Karjalassa. Suomea kutsutaan kappaleessa syöjättäreksi, mikä on epäilemättä viittaus sekä Karjala-keskusteluihin että toisen maailmansodan miehitykseen, jolloin Suomi piti Itä-Karjalaa hallussaan lähes kolmen vuoden ajan. Myös toinen suomenkielinen kappale Surullisessa Jerusalemissa (1990) kritisoi suomalaisia, jotka ovat itsekeskeisiä nautinnonhakijoita, jotka viis veisaavat maailmalla tapahtuvista vääryyksistä - kuten ongelmista Israelissa. Suomi ei siis esiinny missään ihannemaan roolissa Santtu Karhun tuotannossa.

Parodisesti Suomea ja Suomen koloniaalista suhdetta Karjalaan käsitellään Karhun kolmannen singlen kappaleessa Aunuksen Anja (1991). Kyseessä on sotaajan suomalainen iskelmä3 , jonka viesti Karhun ja Talvisopien esittämänä kään-

3 Aunuksen Anja. Sävel Matti Jurva, sanat Tatu Pekkarinen 1942. 
tyy päälaelleen. Kappale kertoo kauniista neuvostokarjalaisesta tytöstä, joka on antanut rukkaset venäläisille politrukille ja komissaarille, Vasilille ja Vanjalle. Itä-Karjalaan on saapunut suomalainen miehityssotilas, Pohjan poika, joka saa "pelastaa" hänet armaakseen. Asetelma, jossa ylemmyyttä tuntevan kansan sankarillinen mies pelastaa kauniin alkuasukasnaisen raakalaisten, siis omien sukulaistensa, käsistä ei ole uusi jälkikoloniaalisen tutkimuksen valossa (Ramnarine 2003: 178-180). Kun raja avautui uudelleen perestroikan aikana, ja Venäjän karjalaiset ja suomalaiset taas kohtasivat, näyttäytyi tämä sota-ajan asetelma irvokkaana: nyt vihollisuuksien sijaan rakennettiin heimoyhteyttä. Sanomansa ansioista kappale saikin melko paljon radiosoittoja Suomessa (Ramnarine 2003; 207; Rinne 1992).

Jos Karhun suhde Suomeen kuvastuu teksteissä piikittelynä, kerrotaan karjaisten ahdingosta rajaseudun asukkaina sitäkin suorasanaisemmin ja jopa katkerammin. Rajan rahvahan blues (Rajan kansan blues 1991) kuvaa sitä, miten rajaseudun karjalaisilla on aina teetetty työtä kuin orjilla; heidät on pantu soutamaan ja työkomennuksille on menty kauas kotoa. Taisteluhalua kuitenkin on: "vuota, nouzemmo, kačommo häijygö tietää", eli odottakaa, mekin pahat vielä nousemme ja katsomme.

\section{Symbolinen ja synkkä}

Suorasanaisten poliittisesti kriittisten tekstien oheen alkoi Santtu Karhun tuotantoon ilmestyä 1990-luvun alussa kasvavassa määrin tekstejä, joiden sisältö oli monitulkintainen, viitteellinen ja symbolinen. Musta lindu -kappaleessa (1990) meren rannasta nousee palava nainen, joka imettää maata maidolla, joka on verta. Ilmassa on uhkaa, musta lintu lentää. Tekstissä on rocklyriikan psykedeliaa ja synkkyyttä, ja sitä samaa on myös sävellyksessä. Konveijerun (Liukuhihnan 1991) yhteiskunnalliset vertauskuvat kertovat työn tekemisen hyödyttömyydestä: mustaa kissaa etsitään mustasta talosta ja täitä kaljusta päästä. Ihmiset on koottu liukuhihnalle.

Kevät (1992) oli yksi Talvisopien tunnetuimmista 1990-luvun kappaleista. Vaikka sitä ei levylle tallennettukaan, esitettiin sitä hyvin paljon keikoilla. Kansansoitinten, haitarin ja jouhikon sekä sähkökitaran rankka yhteissointi kannat- 
telee riffeihin perustuvaa kappaletta. Teksti on täynnä absurdeja, inhorealistisia kielikuvia nostalgisen talonpoikaisesta, mutta hyvin likaisesta Karjalasta. Aurinko muuttuu päreeksi, varis kukoksi, kylän naiset yhteisiksi, poika on upporikas, mutta käsi on tyhjä. Tarjolla on täiturkillinen tavaraa, kaksi ortta jalkarättejä, sormustimellinen jauhoa ja lihoava hiirenjalka. Kummallinen Karjala jatkuu toisessa säkeistössä: Lapsi oli suuri, pirtti pieni, sauna paloi. Torakat nuoleskeltiin, lutikat pureskeltiin.

Symbolista voimaa löytyy kappaleesta Virtytys (Kade silmä 1992), jonka päähenkilö osaa käärmeen sanat ja suudelmat, mutta kuolee siihen. Ei omaa taitamattomuuttaan, vaan jonkun toisen synninteon tähden. Sävellykseltään kappale on hypnoottisen energinen perustuen karjalaisen kansansoittimen jouhikon ja rock-yhtyeen yhteissointiin. Hyvin rauhallinen on sen sijaan Kun yö alkaa (1993), joka kertoo hullusta teatterista ja näyttelijöistä, joita laulaja-minä ohjailee ja rankaisee sanoillaan. Yhteiskunnallinen linkki tekstiin löytyy toisesta säkeistöstä: heimoveljeys ei enää pelasta Karjalaa. Toisessakin erittäin kauniissa ja rauhallisessa kappaleessa nimeltään Keldaine kuu on surumielinen sanoma, jossa puhe pienistä uhanalaisista kansoista yhtyy puheeseen luonnonsuojelusta: Karjalan metsät on kaadettu ja kansa makaa haudassaan.

Yksinäzen hongan juures

On pienen rahvahan luut..
Yksinäisen hongan juuressa

On pienen kansan luut

Karhun tekstit alkavat saada yhä pessimistisemmän sävyn. Kansan kohtalo samastuu luonnon tuhoamiseen, aivan kuten monissa kriittisten neuvostokirjailijoiden teoksissakin ${ }^{4}$.

\section{Lapsista ja perheestä}

Santtu Karhun ja Talvisovat-yhtyeen toiminta hiljeni huomattavasti 1990-luvun puoliväliä lähestyttäessä. Suomalainen pieni levy-yhtiö EiNo Records, joka oli tuottanut kolme ensimmäistä singleä, ei pyrkimyksistään huolimatta pystynyt

4 Esimerkiksi Jaakko Rugojevin romaanissa Ruokoranta (1980) on metsän ja karjalaisen hautausmaan tuhoaminen keskeinen teema. 
julkaisemaan Karhun kokonaista albumia, vaikka materiaalia olisi kyllä ollut (Karhu haastattelu 2011; EiNo kirje 1995). Keikkapyynnöt vähenivät, yhtye hajaantui.

Santtu Karhu sai Karjalan Sivistysseuralta Suomesta apurahan lastenlaulukasetin tekemistä varten. Kurret-albumin ilmestyessä $1997^{5}$ Karhulla itsellään oli pieni tyttö, joka toimi inspiraation lähteenä levyn kappaleille (Karhu, suullinen tiedonanto). Čibi-čibi linduine (Tipu-tipu lintuinen 1997, 2003) on kaunis lastenlaulu, jossa on karjalaisten lorujen tapaan mielikuvituksellisia tapahtumia: "kiiskien kisatessa, ahventen ajellessa - - kuuluu jyry Jyrkilässä, paha pajo pappilassa". Mutta teksti kääntyy pian karhumaisesti absurdismiin, härkä haukkuu, koira mylvii ja "kaikki on päälaellaan". Tekstin epäsovinnaisuudesta huolimatta kappale on yleisilmeeltään hyvin kaunis ja herttainen lapselle omistettu kappale.

Magua pikkarazeni (Nuku pikkuiseni 1997, 2003) on kaunis kehtolaulu. Sen sanasto on kehtolauluille tyypillinen ja tyynen onnellinen: uni on oven takana, se johdattaa pienen "prinsessaisen" lepoon.

$\begin{array}{ll}\text { Magua pieni pelvaspiä, } & \text { Nuku pieni pellavapää, } \\ \text { väzymykses ei jälgie jiä } & \text { väsymyksestä ei jälkeä jää } \\ \text { Syötät linnut kämmenes, } & \text { Syötät linnut kämmenestä, } \\ \text { juokset jallat kasties } & \text { juokset jalat kasteessa } \\ \text { Tyynel aigua huondeksel } & \text { Tyynessä aamussa } \\ \text { muhahtelei päiväzel } & \text { hymyile auringolle } \\ \text { Nygöi silmät ummista, } & \text { Nyt silmät ummista, } \\ \text { älä minuu unohta. } & \text { älä minua unohda. }\end{array}$

Myös muussa tuotannossaan Karhulla on runsaasti perhekeskeisiä tekstejä. Itkuvirzi (Itkuvirsi 1989) perustuu vienankarjalaiseen perinnetekstiin lastaan ikkunassa kaipaavasta äidistä. Edenöj (Etana 1991) on lastenlorun vääntelyyn perustuva teksti. Nogehises kylys (Savusaunassa 2009) kertoo puolestaan kätilöstä, joka saunassa synnytystä avustaessaan näkee lapsen tulevaisuuteen, osin huoliinkin, vanhaa sanontaa siteeraten "hyvä kello kauas kuuluu, paha kauemmaksi".

Erittäin kaunis on kosimisesta kertova Regipajo (Rekilaulu 2001, 2003). Tyylillisesti se on lähellä kansanrunoja ja sanastossa vilisee luonto, talonpoikaistyö ja

5 Kurret-kasetin materiaali on julkaistu uudelleen äänitettynä Suomessa vuonna 2012. 
siihen kuuluvat välineet. Entisen kyläelämän hyvinvointiin kuulunut hevonen on aihe, joka toistuu useissa Karhun kappaleissa.

Minä val'l'astan tulizen hevon

koivuzen korjazen edeh

Jovvun unohtamah mečän vevon,

hevon ragaičen armahalluo

Pajuo jorkotan udžvazeh meččäh,

korbi kajahtah loittozel torvel...

Ajan päiväzeh päi ozan eččoh,

hebuo ragaičen armahalluo
Minä valjastan tulisen hevosen

Koivuisen rekeni eteen

Joudun unohtamaan metsän vedon

Hevosen piiskaan armaani luo

Laulan lauluni usvaiseen metsään

Korpi vastaa kaukaisin torvin

Ajan aurinkoon onneni perään

Hevosen piiskaan armaani luo

Luonnonläheinen on myös Taloi salos (Talo salossa 2006), joka perustuu korvenraivaajan romanttiseen mentaliteettiin ja Karjalan luonnon kauneuteen: "Tein talon, tupaan laitoin tulen, uneksin ja unta näin lapsuudesta, olin pienenä paimenena. Tuolloin silmät eivät vielä olleet kipeät, iho haavoilla, eikä pää raskas". Unelmien korvessa, talonrakentajana, nykyisen elämän karuus ja vaikeudet eivät ole vaivoina.

Kaikissa perhekeskeisissä lauluissa ei suinkaan ole auvoinen ja onnellinen tunnelma. Armoittoman lapsen uni (Orpolapsen uni 2001, 2003) kuvaa pahan äitipuolen kasvattamaa lasta. Riitaisassa perheessä kasvaa katkera ihminen, "viha aina mielessä, kivi kädessä". Onnellisessa perheessä kasvanut ei voi ymmärtää orvon kostonhimoisia unelmia.

Lähti mučoi tänä huondes (Vaimo lähti aamulla 2006) on synkkä laulu vaimosta, joka lähtee aamulla ani varhain maailmalle. Hyvästä tahdosta huolimatta hän menettää mukaansa ottamat hopeat ja kullat. Teksti on vertauskuvallista, ja sen kauniisti soljuvat säkeet muistuttavat kalevalaista kansanlaulua. Kauneuteen kätkeytyy kuitenkin uhkaa.

Lähtibo mučoi tänä huondes

Enne kukoin laulamistu

Pezi pertin, pienen pertin

Tinaizilgo lehtyzil

Vaskizilgo varbaizilgo

Kuldazilgo höyhenil
Lähtipä vaimo tänä aamuna

Ennen kukon laulamista

Pesi pirtin, pienen pirtin

Tinaisilla lehdillä

Vaskisilla varvuilla

Kultaisilla höyhenillä 
Rajaseutua kuvatessaan Karhun maailmankuva on perhekeskeinen ja kyläkeskeinen. Isoisät ja isoäidit ovat lauluissa kunnioitettuja hahmoja ja perheen dynamiikka keskiössä. Ilmaisu, joka sopii näiden aiheiden kuvaamiseen, on alkusointujensa ja sanastonsa puolesta lähellä perinteistä karjalaista runoutta. Mutta myös synkkiä sävyjä ja nurinkurisia kielikuvia on mukana. Aina ei elämässä onni ole myötä. Aivan kuten kirjailija Arvi Pertun romaaneissa (2001; 2006), myös Santtu Karhun lauluissa on läsnä kansallisen yhteisön kriisi.

Karhun aiempi tuotanto pääsi vihdoin cd-levyille julkaistavaksi 200o-luvun alussa. Albuminsa Pahoin brihoin pajatukset Karhu teki yhdessä kitaristi Fedor Astashovin kanssa. Sen myötä Karhulle avautui myös mahdollisuus päästä suomalaisen levy-yhtiön, Hot Igloon tuottamaksi. Yhteistyön myötä on julkaistu tähän mennessä kolme albumia: Hyvästi Karjala (2003), Terveh Petroskoi (2006) ja Allus oli muna (2009). Ensimmäisellä niistä osa kappaleista on samoja kuin Karhun omakustannejulkaisuilla, mutta uutta tuotantoa on riittänyt tämän jälkeenkin.

\section{Periksiantamista}

Karjalaisten parissa 1990-luvun alussa virinneistä toiveista huolimatta, heidän poliittinen asemansa ja karjalan kielen elvytys eivät vahvistuneet Neuvostoliiton hajoamisen jälkeenkään (Kovaleva 2010; Lahikainen \& Mashin 1993). Samanaikaisesti elintaso kehittyi hitaasti ja maan talousjärjestelmä oli vaikeuksissa. Poliittinen avoimuus jäi sekin osittain toteutumatta. Karhun teksteissä 200o-luvun alussa nykyisyys näyttäytyi näköalattomana. Se vertautui menneisyyteen, aikaan jolloin maaseudun karjalaisilla oli elämä omissa käsissään. Erityisesti albumeilla Hyvästi Karjala ja Terveh Petroskoi näkökulman muutos näkyi teksteissä. Ihannoiva nostalginen kuvailu vaihtui irvokkaaseen sarkasmiin Karjalasta tuhon partaalla. Hyvästi Karjalan teksteistä monet ovat edellä mainittuja perhekeskeisiä kyläkulttuuriin asemoituvia kappaleita. Yhtye käynnistyi uudelleen näitä albumeja varten. Karhu itse soitti niissä ensin sähköbassoa ja myöhemmin mandoliinia, kitaraa ja steel-kitaraa.

Izo seppy Ilmollinen (Suuri seppä Ilmarinen 2003) kutsuu karjalaisten vanhoja jumalia apuun. Nykypäivän Karjalasta on jäänyt pelkkä nimi, karjalaiset ovat kärsineet rajan levottomuuksista ja hajaantuneet laajalle alueelle aina Tverin Kar- 
jalaan saakka. Kappaleeseen sisältyy puhuttu johdanto, kertomus Karjalan historiasta, rajasodista ja jumalista. Kalevalainen sankari Seppä Ilmarinen on menneen ajan kuva, kun taas laulun kertosäkeistössä näyttäytyy lohduton Karjala: "Kylät papittomat, pellot aidattomat, hautausmaat tsasounattomat".

$\begin{array}{ll}\text { Izo sepp' olet Ilmalline, } & \text { Iso seppä olet Ilmarinen } \\ \text { raudua tavot voimalline } & \text { Rautaa taot voimallinen } \\ \text { Sinuu tänne tahtotahe, } & \text { Sinut tänne tahdotaan } \\ \text { sinuu tanne tarvitahe } & \text { Sinut tänne tarvitaan } \\ \text { Tule tuhanzis miehis turbein, } & \text { Tule mies turpein tuhansista } \\ \text { tule savois sangein } & \text { Tule sadoista sankein } \\ \text { Tule roduu piästämähe, } & \text { Tule heimoa päästämään } \\ \text { Tule suguu pellastamah } & \text { Tule sukua pelastamaan }\end{array}$

Eritysesti albumi Terveh Petroskoi on teemaltaan yhtenäinen. Karjala näyttäytyy perestroikan jälkeen häpeälliseltä verrattuna sen menneeseen viattomuuteen ja puhtauteen. Sitä katsoessa etäisyys historiaan kasvaa ja suru ja katkeruus lisääntyvät. Avauskappaleen Huolevil huondeksuzil (Kiireisinä aamuina) kertosäkeistö kysyy: "Pitääkö, äiti, pestä puhtailla vesillä, raikkailla vesillä, vai kyynelillä".

Hyllätty ei ole hullattu (Hylätty ei ole halvaantunut) kertoo vääristä valinnoista. Poika lyö päätään seinään juoden viinaa ja nuori nainen ei kevytmielisyytensä tähden tiedä kenen lasta odottaa. Vanhemmatkaan eivät ole viisaampia. Ukko tavoittelee nuoria naisia ja akka on tyhjänpuhuja juoruilija. Kovakorvaisiin on turha asettaa toivoa, kuten sananparren omaisessa kertosäkeistössä sanotaan: "ei kuuron papin tähden kelloja halkaista".

Kertoja on kelvoton kuljeksija kappaleessa Kehnon kegälehen osa (Kehnon hiilen kohtalo). Hän ei osaa asettua eikä saa hoidettua velvollisuuksiaan. Vanhan kansan sanonnat ovat kulkijalla mielessä, mutta kotia hänellä ei enää ole, eikä voimaa vastustaa omia mielitekojaan.

Syvällisimmin laulaja pohtii kulkevaa renttuilevaa elämäänsä kappaleessa Mies tutah tulendas (Mies tunnetaan askelistaan). Hän ei suostu valjaisiin, tappelee ja saa tytöt pelkäämän häntä. Nauraen häntä saatetaan hautaan. Vaihtoehto tälle elämäntavalle nousee kertosäkeistössä: olisiko parempi asettua vai elää vapaana, ovatko nämä ääripäät ainoat vaihtoehdot. 
Ongo lagi vai taivas

Ylähän pahan brihan piäl ainos tiel...

Ongo helmas vai kalmas

Oza parembi nuorel miehel...
Onko katto vai taivas

aina pahan pojan päällä täällä?

Onko helmass' vai kalmass'

Paikka parempi miehen nuoren?

Samaan tapaan kappaleessa Eigo ole huigei (Eikö ole häpeä) kertoja-minä jättää vaimonsa ja arkisen elämänsä, kuljeskelee masentuneena kädet taskuissa, on kyllästynyt akan itkuun ja hevosen hikeen, siis kurjuuteen ja kovaan työhön. Veli häntä ilkkuu, mutta laulaja ihmettelee, miksi tämä jäi murehtimaan. Eikö rohjennut tempaista itseään arjen ankeudesta?

Varhaistuotantoon verrattuna karjalainen nostalginen kyläelämä ei välttämättä enää näyttäydykään vaihtoehtona, vaan yhtä lailla nykyisyys kuin muisto entisestäkin antavat aihetta juopottelulle ja kuljeskelulle. Perestroikan ajan taistelunhalu on korvautunut alistuneella asenteella, hämmennyksellä ja moitteilla. Kysymyksiin ei saada vastauksia. Yhteisöllisyys, jota kuvasi alkutuotannon karjalaisiin kansana viittaava me-muoto sanoituksissa, on liudentunut perhesuhteiden käsittelyksi ja siinäkin useasti vailla sopusointua ja rauhaa.

\section{Venäläistyvä paha maa}

Sananvapaus Venäjällä on suhteellinen asia. Monet eivät uskalla edes lauluissa sanoa suoraan, mitä ajattelevat politiikasta (Bogdanov, haastattelu 2011; Demin haastattelu 2011); lehtiä sensuroidaan, taiteilijoiden työskentelyä vaikeutetaan. Karhu on omalta osaltaan kohdannut ongelmia, eikä muun muassa harjoitustilaa yhtyeelle ole löytynyt huolimatta siitä, että Karjalan tasavallan kulttuuriministeriö tukee muita vastaavia petroskoilaisia folkrock-yhtyeitä. Ministeri Elena Bogdanovan mukaan syynä on liika vodkan juominen (Bogdanova, haastattelu 2011). Karhu itse epäilee vaikeuksistaan, että hän on liian suorasuinen ja ironinen nykypolitiikan ja venäläisyyden arvostelija (Karhu, haastattelu 2011).

Uusimman levynsä (Allus oli muna 2009) avausraita Moskovan kämmen on selväsanaisen poliittinen. Siinä asetelmana on nurin kääntynyt, poliittisesti järkkynyt maailma. Yöllä on kuuma, päivällä vilu, ukko värjöttelee uuninsa ääressä. 
Susiedu velli kiändyi sellin

Konzu vahnus leibiä pakičči

Diedol pidi mustoittua

Kuule velli oružas on liipačin
Naapurin veli kääntyi selin

kun vanhus leipää kerjäsi

ukkia piti muistuttaa

kuule veli aseessa on liipasin

Ukko kääntyy pulassaan naapurin, venäläisen puoleen, mutta tämä uhkailee aseella. Kertosäkeistö vahvistaa tulkinnan: "Ei ole lämmin, Moskovan kämmen. Se tarjoaa suukkoa, mutta iskeekin puukolla." Jos venäläiset ylenkatsovat hätää kärsiviä karjalaisia, ei laulussa olla suopeita moskovalaisiinkaan nähden: tavoiltaan oudot pääkaupunkilaiset ovat haisevia, näivettyneitä ja epäystävällisiä.

Muut levyn kappaleet kuvaavat särkynyttä Karjalaa. Osassa on ironinen sävy, osassa taas itseä ruoskiva tuskainen ääni. Valgei vällys (Valoisa vapaus) tuntuu kertovan luopiosta, joka on valmis käymään kauppaa kaikesta, jopa omasta maastaan. Hänestä on tullut korkea herra, mutta onneton, voimaton ja tolkuton. Ulkopuolisuuden kokemuksesta kertoo Olen vieraz (Olen vieras). Kuva näyttäisi sopivan Karhuun itseensä. Hän on joutunut outoon maailmaan, ääni on käheä, mutta kulku on kepeä jos rekeä vetävä hevonen on voimissaan. Laulajan pohjaton murhe on kääntynyt kiukuksi ja vihaksikin.

Rokkua luzikattah (Soppaa lusikatta) kertoo juoposta, joka on hylännyt onnensa juomisensa tähden. "Ennen oli rikkautta, ne kaikki valuivat kurkkuun. Oli lampaita ja oli hevonen, kuin tuhkat tuuleen ne menivät". Iloisen absurdi on sen sijaan Kois on seinät vois (Kotona ei paremmin olla vois). Se kertoo kyläelämän hupsuista puolista, seksuaalisuudesta ja itsetyydytyksestä. Juominen on aiheena myös kappaleessa Magieh join (Makeasti join), jossa juoppo tekee irrationaalisia asioita, viskelee kissaa ja potkii portaita. Kappaleessa vieraileva petroskoilainen naiskuoro Oma pajo tuo karjalaisen kansankuoron soundin levylle. Naisäänet tuntuvat moittivan laulajaa, juomaria.

\section{Karjalan kielen asia}

Karjalan kielen elvyttämisen kannalta Santtu Karhun merkitystä ei voi yliarvioida. Hän on tuonut katoavan kielen kokonaan uuteen kontekstiin rockyhtyeen ohjelmistoon ja levyille. Tämä on merkinnyt myös kielellistä uudistamista, sillä 
rockin esityskontekstit ja estetiikka vaativat raaempaa, suoraviivaisempaa kieltä kuin estradikansanlaulut. Karhun ansio on sitäkin suurempi, kun ajattelee, että hyvin harvat hänen yleisöstään ymmärtävät hänen laulujensa sanoituksia. Karjalan kieli on suomen kielen läheisin sukukieli, mutta erityisesti sen eteläinen Aunuksen murre (livvi) on niin vaikeaselkoinen, etteivät suomalaiset sitä vaikeuksitta ymmärrä. Sanasto on outoa vaikka kielioppi onkin lähes sama kuin suomessa. Venäläinen yleisö ja nuoret karjalaiset ymmärtävät karjalaa vieläkin vähemmän. Karhun sanojen mukaan hänen yhtyeensä jäsenetkään eivät tiedä, mistä laulut kertovat. Aiheen hän voi kertoa heille, mutta tarkemmin tekstejään hän ei yhtyeen harjoituksissa selitä tai käännä. (Karhu, haastattelu 2006.)

Muista karjalan kielen revivalisteista Santtu Karhu poikkeaa siinä, että hän ei käytä teksteissään livvin kielen (vuodesta 1989 alkaen kehitettyä) standardoitua kirjakielistä muotoa, vaan itselleen läheistä Vieljärven paikallismurretta (kielimuotojen kehityksestä Õispuu 2013). Hän tietoisesti keskittyy ihmisten kanssa keskusteluun, etsii tekstiaineistoja perinnearkistojen julkaisuista ja ylipäätään käyttää erittäin monipuolista ja kieliasultaan korrektia karjalan puhekieltä paikallismurteen kautta omaksuttuna. (Karhu, haastattelu 2011.) Hänen kielikuvansa ja sanastonsa on siksi toisinaan vaikeaselkoista ja hankalasti tulkittavaa. Hänen tekstiensä kielen rikkaus ja perinnesidonnaisuus on jo sinänsä suuri saavutus. Hän ei ole tinkinyt kielellisen ilmaisun korkeista vaatimuksista huolimatta siitä, että hyvin harva ymmärtää hänen tekstiensä sisältöä.

Karjalan kielen katoaminen tuntuu toisaalta myös Santtu Karhun lyriikassa. Arkikielistä keskustelua sanoituksiin ei sisälly, sen sijaan sitäkin enemmän viittauksia vanhoihin kalevalaisen runouden muotoihin ja säkeisiin. Karjalaiset sananparret ovat mukana teksteissä, vaikka suoria sitaatteja niistä on hyvin vähän. Tekstien elämänmakuiset kielikuvat nojaavat enemmän menneeseen aikaan kuin moderniin maailmaan. Karhun uran alkuaikojen Suomi-aiheisia kappaleita ei uran loppupuolella ole esiintynyt, mutta suomalaista yleisöä hän palvelee edelleen kiertueilla, äänitteillä ja konserteissa. Hänestä on tehty useita dokumenttielokuvia ja hänen laulutekstejään on julkaistu runoteoksissa6 ${ }^{6}$ Hänen roolinsa ylirajaisen karjalan kielestä kiinnostuneen yleisön rakentajana on olennainen.

6 Dokumenttielokuvia: Marschan, Elizabeth nd. (1990). Punalippurock. Kaksi marraskuun päivää. Yle, Suomi. Tuominen, Arvo 2002. Talvisovat-yhtye karjalaisuuden jäljillä. YLE 3.12.2002. Nissi, Esa (2005) Santtu Karhu - livvin kielellä. QuetzalCoatl Production Oy, Oulu 2005. 
Santtu Karhun tuotannon suuri arvo on myös sen musikaalinen monipuolisuus, taiteellinen kypsyminen ja syveneminen. Teksteissään Karhu tuntuu siirtyneen 1990-luvun vaihteen optimismista pettyneen karjalaisen synkkyyteen ja sarkasmiin. Musiikillisesti katsoen kehitys on kuitenkin päinvastainen. Alkuaikojen punkhenkisestä paatoksesta ja räiskyvästä rockista on siirrytty taitavaan akustiseen ilmaisuun (Pahoin brihoin pajatukset -levyllä 2001) ja edelleen hallittuun monipuoliseen progevaikutteiseen bändisoundiin (Allus oli muna -levyllä 2009). Santtu Karhu on oleellinen myös 200o-luvulla heränneelle karjalan kielen nuorten aktivistien liikkeelle. Se on vuodesta 2007 alkaen järjestänyt kahdesti vuodessa itämerensuomalaisille kielille omistettuja klubi-iltoja "etnodiskoja", joissa on soittanut Santtu Karhun Talvisopien lisäksi kymmenkunta muuta paikallista itämerensuomalaisilla kielillä laulavaa rock- ja folkyhtyettä. Niiden avulla kieliaktivistien järjestön Nuoren Karjalan jäsenmäärä on moninkertaistunut (Antonova, haastattelu 2010). Näin karjalankieliselle musiikille on ensi kertaa alkanut muodostua oma yleisönsä Petroskoissa. (Suutari 2012.)

Vaikka Santtu Karhun tekstien perusteella hänen idealisminsa on vaihtunut sarkasmiin, on hänessä kuitenkin säilynyt halu toimia, halu tehdä jotain, halu tuottaa musiikkia. Karjalaisia piikittelevien laulutekstien pirullisuudesta huolimatta hän on edelleen keskeisimpiä karjalankielisen kulttuurin toimijoita. Karjala-representaatiot olivat vaihtuneet, neuvostoaikainen tapa esittää kansallisia kulttuureja jäi taka-alalle ja esiin nousi uuden ajan estetiikan myötä uusi vähemmistökulttuurien esittämisen logiikka. Karhun tuotanto näyttää sen, missä tilassa Karjalan paikalliset yhteisöt ovat ja miten yhteiskunnallinen murros on tuntunut heidän arjessaan. Santtu Karhun lauluista tuli kommentteja kielen kuolemalle, kansan tulevaisuudelle ${ }^{7}$ ja karjalaisuuden ihannoimiselle. Paikallisten perinnetekstien tyylin yhdistelemisestä nykypäivän folkrockin estetiikkaan tuli Santtu Karhun tapa tuoda karjalaisuus näkyville. Niissä tuntuu tekijän suhde Karjalaan, ympäröivään yhteiskuntaan ja myös naapurimaahan Suomeen.

7 Etnofuturismista Karhun tuotannossa Bogdanov 2009. Vähemmistökielellä lauletun rockin idea tuli Karhulle ennen muuta Neuvosto-Eestistä, joka oli muuta Neuvostoliittoa vapaamielisempi suhteessa rockiin (Troitski 1988). Sieltä myös levisi etnofuturismiksi kutsuttu liike, joka ihannoi suomalais-ugrilaisten kansojen nousua (Sallamaa 2003). 


\section{Lähdeluettelo}

Karhu, Santtu (2012) Hyvästit Karjala, Terveh Petroskoi! Turku/Tampere: Savukeidas.

Lähteenä Santtu Karhun demoilta kirjoitetut kappaleiden sanat, jotka Timoi Munne on suomentanut Santtu Karhun avustuksella. Tekijän hallussa.

\section{Haastattelut}

Antonova, Natalia 25·3.2010. Nuori Karjala -järjestö, Petroskoi. Haastattelija: kirjoittaja. Bogdanov, Evgenii 14.9.2011. Haastattelijan kotona Petroskoissa. Haastattelija: kirjoittaja. Bogdanova, Elena 19.10.2011. Kulttuuriministeriö, Petroskoi. Haastattelija: kirjoittaja. Demin, Dmitri 9.9.2011. Petroskoin valtionkonservatorio. Haastattelija: kirjoittaja. Karhu, Santtu 7.6.2006. Karhun bändin harjoitustila Petroskoissa. Haastattelija kirjoittaja Karhu, Santtu 7.10.2011. Karhun kotona Petroskoissa. Haastattelija: kirjoittaja.

Karhu, Santtu 28.4.2012. Karhun kotona Petroskoissa. Haastattelija: Timoi Munne.

Kokkonen-Roivas, Tanja 2.10.2011. Haastateltavan kotona Joensuussa. Haastattelija: kirjoittaja. Rinne, Arto 19.10.2011. Rinteen kotona Petroskoissa. Haastattelija: kirjoittaja.

\section{Kirjeet}

Vladimir Brendojevin kirje Santtu Karhulle lokakuussa 1988. Santtu Karhun kotiarkisto. EiNo Recordsin Vesa Kaartisen kirje Arto Rinteelle 1.10.1995. Arto Rinteen kotiarkisto.

\section{Äänitteet}

Rinne, Arto (1992) Radiokuulutus Aunuksen Anja Karjalan radiossa, Petroskoissa. http:/ / heninen.net/talvisovat/rare_f.htm. (Lähde tarkistettu 17.10.2014.) 


\section{Singlet}

Santtu Karhu (1989) Mustas kois / Lykyn peräh. EiNo Records, Eino eis 1.

Santtu Karhu \& Talvisovat (1990) Airotoi veneh / Syvysharmavus. EiNo Records, Eino eis 2.

Santtu Karhu \& Talvisovat (1991) Omien aigoin legendat / Aunuksen Anja. EiNo Records, Eino eis 3 .

\section{Albumit}

Santtu Karhu (1997) Kurret (c-kasetti). Petroskoi: omakustanne.

Santtu Karhu \& Talvisovat (2001) Pahoin brihoin pajatukset. Omakustanne.

Santtu Karhu \& Talvisovat (2003) Hyvästit Karjala. Hot Igloo HI-004.

Santtu Karhu \& Talvisovat (2006) Terveh Petroskoi. Hot Igloo HI-oo6.

Santtu Karhu \& Talvisovat (2009) Allus oli muna. Hot Igloo HI-oog.

Santtu Karhu \& Talvisovat (2009) E.L.O.S. Nuori Karjala. [ei tunnusta]

Santtu Karhu (2012) Kurret. Joensuu: Karjalan kielen seura. KKSCD-001.

Santtu Karhu \& Talvisovat. Demoja 1988-1996. Arto Rinteen kotiarkisto, Petroskoi.

\section{Kirjallisuus}

Berger, Harris M. (2008) “Phenomenology and the Ethnography of Popular Music.

Ethnomusicology at the Juncture of Cultural Studies and Folklore". Shadows in the Field.

New Perspectives for Fieldwork in Ethnomusicology. Toim. Gregory Barz \& Timothy J.

Cooley (2 ${ }^{\text {nd }}$ edition). Oxford: Oxford University Press. Ss. 62-75

Birin, Viktor (1996) "Kansalliset liikkeet Karjalan tasavallan yhteiskunnallisessa murroksessa".

Matkalla kansalaisyhteiskuntaan? Liikettä ja liikkeitä Luoteis-Venäjällä. Toim. Ilkka Liikanen

\& Pentti Stranius. Joensuu: Karjalan tutkimuslaitoksen julkaisuja. Ss. 27-41.

Bogdanov, Jevgeni (2009) "Features of Karelian Ethno-Futurism. Notes on the Values and World of Ideas of Rock Lyricist Santtu Karhu". Kantele, runolaulu ja itkuvirsi. Toim. Pekka HuttuHiltunen, Frog, Eila Stepanova \& Janne Seppänen. Kuhmo: Juminkeko.

Bruner, Edward (1986) "Ethnography as narrative". The Anthropology of Experience. Toim.

Victor W. Turner \& Edward M. Bruner. Urbana and Chicago: University of Illinois Press. 
Grünthal, Riho (2009) "Kieliyhteisön rapautuminen ja kielellisen identiteetin muutos". Kielissä kulttuurien ääni. Toim. Anna Idström \& Sachiko Sosa. Helsinki: Suomalaisen Kirjallisuuden Seura.

Hirsch, Francine (1997) “The Soviet Union as Work-in-Progress: Ethnographers and the Category Nationality in the 1926, 1937, and 1939 Censuses". Slavic Review 56: 2, ss. $251-278$.

Ilyukha, Ol'ga (toim.) (2005) Mezhkul'turnye vzaimodeistviia v polietnitshnom prostranstve pogranitshnogo regiona. Petrozavodsk: Rossiiskaia Akademiia Nauk.

Joustavat etnisyydet (2014) Tutkimushankkeen kotisivu www.uef.fi/fe. Luettu 22.8.2014. Järviluoma, Helmi (2010) "Podetko ystävyyttä? Etnografia ja biofilian haaste". Vaeltavat metodit. Toim. Jyrki Pöysä, Helmi Järviluoma \& Sinikka Vakimo. Joensuu: Suomen kansantietouden tutkijain seura. Ss. 234-257.

Jones-Bamman, Richard (2006) “From 'I'm a Lapp' to 'I am Saami'. Popular Music and Changing Images of Indigenous Ethnicity in Scandinavia". Ethnomusicology. A Contemporary Reader. Toim. Jennifer C. Post. New York \& London: Routledge.

Kaartinen, Vesa (1989) "Santtu Karhu levytti Lännessä". Punalippu 11/1989.

Kisliuk, Michelle (2008) "(Un)doing Fielwork. Sharing Songs, Sharing Lives". Shadows in the Field. New Perspectives for Fieldwork in Ethnomusicology. Toim. Gregory Barz \& Timothy J. Cooley ( $2^{\text {nd }}$ edition). Oxford: Oxford University Press.

Klement'ev, E. I. (1991) Karely. Etnografitsheskii otsherk. Petrozavodsk: Kareliia.

Kovaleva, Svetlana (2010) "Nekotorye aspekty sovremennoi yazykovoi situatsii v Karelii". Karelia Written and Sung. Representations of Locality in Soviet and Russian Contexts. Toim. Pekka Suutari \& Yury Shikalov. Helsinki: Kikimora, Ss. 29-49.

Kurki, Tuulikki (2010) “The Modern Soviet Man Looks Back. Images and Narratives of Soviet Karelia". Karelia Written and Sung. Representations of Locality in Soviet and Russian Contexts. Toim. Pekka Suutari \& Yury Shikalov. Helsinki: Kikimora, Ss. 86-108.

Lahikainen, Kaisu \& Mashin, Armas (toim.) (1993) Kaikuja Karjalasta. Helsinki: Ajatus.

Laine, Antti (2002) "Rise and Fall of Soviet Karelia. Continuity and Change in the $20^{\text {th }}$ Century Russia". Rise and Fall of Soviet Karelia. Toim. Antti Laine \& Mikko Ylikangas. Helsinki: Kikimora.

Mironova, Valentina (2010) "Fol'klornye motivy v kareloyazytshnoi literature (na primere tvortshestva Vladimira Brendoeva)". Karelia Written and Sung. Representations of Locality in Soviet and Russian Contexts. Toim. Pekka Suutari \& Yury Shikalov. Helsinki: Kikimora, Ss. $159-176$. 
Moisala, Pirkko (2013) "Etnomusikologian uudet haasteet". Musiikki kulttuurina. Toim. Pirkko Moisala \& Elina Seye. Helsinki: Suomen Etnomusikologinen Seura, Ss. 9-25.

Nettl, Bruno (1983) The Study of Ethnomusicology. Twenty-nine Issues and Concepts. Urbana \& Chicago: University of Illinois Press.

Olson, Laura J. (2004) Performing Russia. Folk Revival and Russian Identity. London \& New York: RoutledgeCurzon.

Paskov, Aleksander (2012) "The Research of the White Sea Karelians by Russian scholars during the reign of Alexander II (1855-1881)". Nation Split by the Border. Changes in the ethnic identity, Religion and Language of the Karelians from 1809 to 2009. Toim. Tapio Hämynen \& Aleksander Paskov. Joensuu: University Press of Eastern Finland.

Perttu, Arvi (2001) Petroskoin symposium. Petrozavodsk: Verso.

Perttu, Arvi (2006) Papaninin retkikunta. Jyväskylä: Minerva.

Ramnarine, Tina K. (2003) Ilmatar's Inspirations. Nationalism, Globalization and the Changing Soundscapes of Finnish Folk Music. Chicago: University of Chicago Press.

Rice, Timothy (1994) May It Fill Your Soul. Experiencing Bulgarian Music. Chicago \& London: The University of Chicago Press.

Sallamaa, Kari (2003) "Etnofuturismi toiselle vuosikymmenelleen". Viron kirjallisuus vuosituhannen vaihteessa. Toim. Liisa Saariluoma, Tarja Pakarinen \& Piret Kruuspere. Helsinki: sKs.

Shvetsova, Vera I. (toim.) (2007) Etnitsheskaya muzyka i xxI vek. Petrozavodsk: Izdatel'stvo Petrozavodskogo universiteta.

Sihvo, Hannes (2003) [1973] Karjalan kuva. Karelianismin taustaa ja vaiheita autonomian aikana. Helsinki: Suomalaisen Kirjallisuuden Seura.

Smith, Jeremy (2013) Red Nations. The Nationalities Experience in and after the UssR. Cambridge University Press.

Suutari, Pekka (2010a) "Introduction. Locality - Representations and Practices". Karelia Written and Sung. Representations of Locality in Soviet and Russian Contexts. Toim. Pekka Suutari \& Yury Shikalov. Helsinki: Kikimora, Ss. 5-14.

Suutari, Pekka (2010b) "Representation of Locality in Karelian Folk Music Activities from Composers to Singing Women". Karelia Written and Sung. Representations of Locality in Soviet and Russian Contexts. Toim. Pekka Suutari \& Yury Shikalov. Helsinki: Kikimora, Ss. 209-228. 
Suutari, Pekka (2012) “Fol’klornye traditsii i molodoe pokolenie prigranitsh'ja: Natshalo tvortsheskogo puti ansamblja “Toive" (1982-1992)". Trudy. Karel'skogo nautshnogo tsentra. 4/2012. Petrozavodsk: Rossiiskoj akademii nauk.

Suutari, Pekka \& Munne, Timoi (2013) "Santtu Karhu ja karjalaisen perinteen puristus". Viisas matkassa, vara laukussa. Näkökulmia kansanperinteen tutkimukseen. Toim. Tuomas Hovi, Kirsi Hänninen, Merja Leppälahti \& Maria Vasenkari. Turku: Turun yliopisto, Folkloristiikan julkaisuja.

Troitsky, Artemi (1988) Terveisiä Tsaikovskille. Helsinki: Vastavoima.

Ylikangas, Mikko (2004) Rivit suoriksi! Kaunokirjallisuuden poliittinen valvonta NeuvostoKarjalassa 1917-1940. Helsinki: Aleksanteri-instituutti.

Zhukova, V. A. (1990) Otsherki muzykal'noj kul'tury Karelii. Petrozavodsk: Petrozavodskoe muzykal'noe utshilishtshe im. K. E. Rautio.

Õispuu, Jaan (2013) "Painettu sana pitää kansaa koossa. Vertaileva katsaus Aunuksenkarjalan ja Viron kirjallisuuden historiaan". Karjala-kuvaa rakentamassa. Toim. Pekka Suutari. Helsinki: Suomalaisen Kirjallisuuden Seura. Ss. 108-121. 